\title{
Testing and Oxygen Assessment Results for a Next Generation Extravehicular Activity Portable Life Support System Fan
}

\author{
Heather L. Paul ${ }^{1}$ \\ NASA Johnson Space Center, Houston, Texas 77058 \\ Mallory A. Jennings ${ }^{2}$ \\ NASA Johnson Space Center, Houston, Texas 77058 \\ Fatonia L. Rivera ${ }^{3}$ \\ Jacobs Engineering, Houston, Texas 77058 \\ and \\ Devin Martin \\ Wyle Laboratories, Houston, Texas 77058
}

\begin{abstract}
NASA is designing a next generation Extravehicular Activity (EVA) Portable Life Support System (PLSS) for use in future surface exploration endeavors. To meet the new requirements for ventilation flow at nominal and buddy modes, a fan has been developed and tested. This paper summarizes the results of the performance and life cycle testing efforts conducted at the NASA Johnson Space Center. Additionally, oxygen compatibility assessment results from an evaluation conducted at White Sands Test Facility (WSTF) are provided, and lessons learned and future recommendations are outlined.
\end{abstract}

\footnotetext{
${ }^{1}$ Ventilation Lead, Space Suit and Crew Survival Systems Branch, 2101 NASA Parkway, Houston, Texas 77058.

${ }^{2}$ Project Engineer, Space Suit and Crew Survival Systems Branch, 2101 NASA Parkway, Houston, Texas 77058.

${ }^{3}$ Project Manager, Engineering and Science Contract Group, Org\# 4340, 2224 Bay Area Blvd., Houston, Texas 77058/ JE-B21N.
} 


\title{
Testing and Oxygen Assessment Results for a Next Generation Extravehicular Activity Portable Life Support System Fan
}

\author{
Mallory A. Jennings ${ }^{1}$ \\ NASA Johnson Space Center, Houston, Texas 77058 \\ Heather L. Paul ${ }^{2}$ \\ NASA Johnson Space Center, Houston, Texas 77058 \\ and \\ Devin Martin ${ }^{3}$ \\ Wyle Laboratories, Houston, Texas 77058
}

\section{Abstract}

NASA is designing a next generation Extravehicular Activity (EVA) Portable Life Support System (PLSS) for use in future surface exploration endeavors. To meet the new requirements for ventilation flow at nominal and buddy modes, a fan has been developed and tested. This paper summarizes the results of the performance and life cycle testing efforts conducted at the NASA Johnson Space Center. Additionally, oxygen $\left(\mathrm{O}_{2}\right)$ compatibility assessment results from an evaluation conducted at White Sands Test Facility (WSTF) are provided, and lessons learned and future recommendations are outlined.

\section{Introduction}

Space suit life support systems for future surface exploration will need to be lightweight, robust, reliable, and efficient to optimize overall system operation. Requirements development of such systems has revealed the need for a fan, under nominal operation, to control carbon dioxide and humidity levels within the space suit helmet and to pressurize the space suit. The fan must also operate in a secondary mode, known as "buddy mode." Buddy mode is the emergency scenario associated with failure of one Portable Life Support System (PLSS) such that it is no longer operational and one fan would provide ventilation flow to two space suits connected in series. A third design scenario, called the "Maximum Flow Point" is also under consideration, in the event that the current requirements for nominal conditions are not adequate for washout of carbon

\footnotetext{
${ }^{1}$ Project Engineer, Space Suit and Crew Survival Systems Branch, 2101 NASA Parkway, Houston, Texas 77058.

${ }^{2}$ Space Suit PLSS Engineer, Space Suit and Crew Survival Systems Branch, 2101 NASA Parkway, Houston, Texas 77058.

${ }^{3}$ Test Engineer, Bioastronautics Contract/ Flight Hardware Group, 1290 Hercules Dr. Suite 130, Houston, TX 77058.
} 
dioxide and humidity in the space suit helmet. Figure 1 shows the PLSS schematic with the fan positioned and noted as "FN-300" [1].

This paper summarizes the results of the fan performance and life cycle testing efforts conducted at the NASA Johnson Space Center (JSC) at atmospheric and subatmospheric pressures. Test data is presented to show how the fan performed relative to the ventilation requirements for the EVA Portable Life Support System. Additionally, oxygen compatibility assessment results from an evaluation conducted at White Sands Test Facility (WSTF) are provided, and lessons learned and future recommendations are discussed.

Revision: $B$

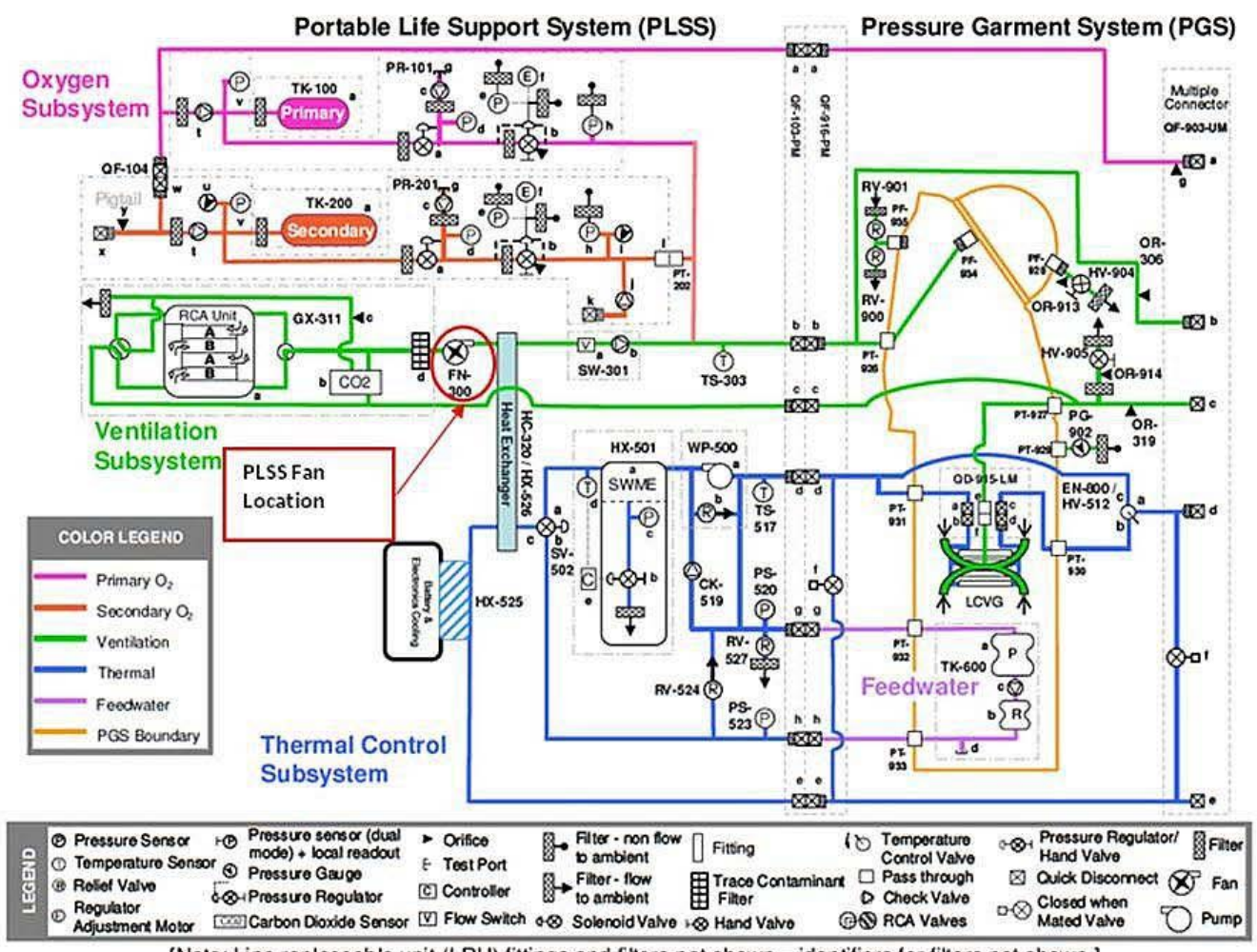

[Note: Line replaceable unit (LRU) fittings and filters not shown - identifiers for filters not shown.]

Figure 1: PLSS Schematic [1]

\section{PLSS Fan Development Unit}

A centrifugal fan, in this paper referred to as the "PLSS Fan Development Unit," was designed, built and tested at the vendor site to meet a set of operational requirements as defined in Table 1 [2]. The PLSS fan development unit consists of a centrifugal impeller to create ventilation flow, a motor to turn the impeller, and a housing to direct the ventilation flow. These features can be seen in Figure 2 and are individually identified in Figure 3. Ventilation flow enters the fan axially and is propelled in the radial direction by the impeller where it then proceeds to enter a radial diffuser. The diffuser turns the dynamic pressure from the fan into total pressure to increase the performance of the fan and reduce acoustic noise. From the radial diffuser the ventilation gas passes 
into a volute and then out to a conical diffuser that allows the high speed ventilation gas leaving the volute to expand in a controlled manner.

Table 1: Fan Assembly Requirements

\begin{tabular}{|c|c|c|c|}
\hline Parameter & Design Point & Buddy Point & Max Flow Point \\
\hline $\begin{array}{c}\text { Fan Assembly } \\
\text { Overall Power (W) }\end{array}$ & 14 & - & - \\
\hline $\begin{array}{l}\text { Motor Input Power } \\
\text { (W) }\end{array}$ & 6 & - & - \\
\hline Mass (kg/lbm) & $0.91 / 2.0$ & same & same \\
\hline $\begin{array}{l}\text { Volume Envelope } \\
\qquad\left(\mathrm{m}^{3} / \mathrm{in}^{3}\right)\end{array}$ & $4.9 \times 10^{-4} / 30$ & same & same \\
\hline $\begin{array}{c}\text { Flow \& Pressure } \\
\text { Rise }\left(\mathrm{m}^{3} / \mathrm{sec} \& \mathrm{~Pa}\right) \\
\text { or }(\mathrm{cfm} \& \text { inches of } \\
\left.\mathrm{H}_{2} \mathrm{O}\right)\end{array}$ & $\begin{array}{c}2.22 \times 10^{-3} / 672 \\
4.7 \mathrm{cfm} / 2.7 \text { inches } \\
\mathrm{H}_{2} \mathrm{O}\end{array}$ & $\begin{array}{c}4.44 \times 10^{-3} / 1681 \\
9.4 \mathrm{cfm} / 6.75 \text { inches } \\
\mathrm{H}_{2} \mathrm{O}\end{array}$ & $\begin{array}{c}2.8 \times 10^{-3} / 1021 \\
5.9 \mathrm{cfm} / 4.1 \text { inches } \\
\mathrm{H}_{2} \mathrm{O}\end{array}$ \\
\hline $\begin{array}{l}\text { Inlet Conditions } \\
\text { (Pa/psia) }\end{array}$ & $29,649 / 4.3$ & same & same \\
\hline
\end{tabular}

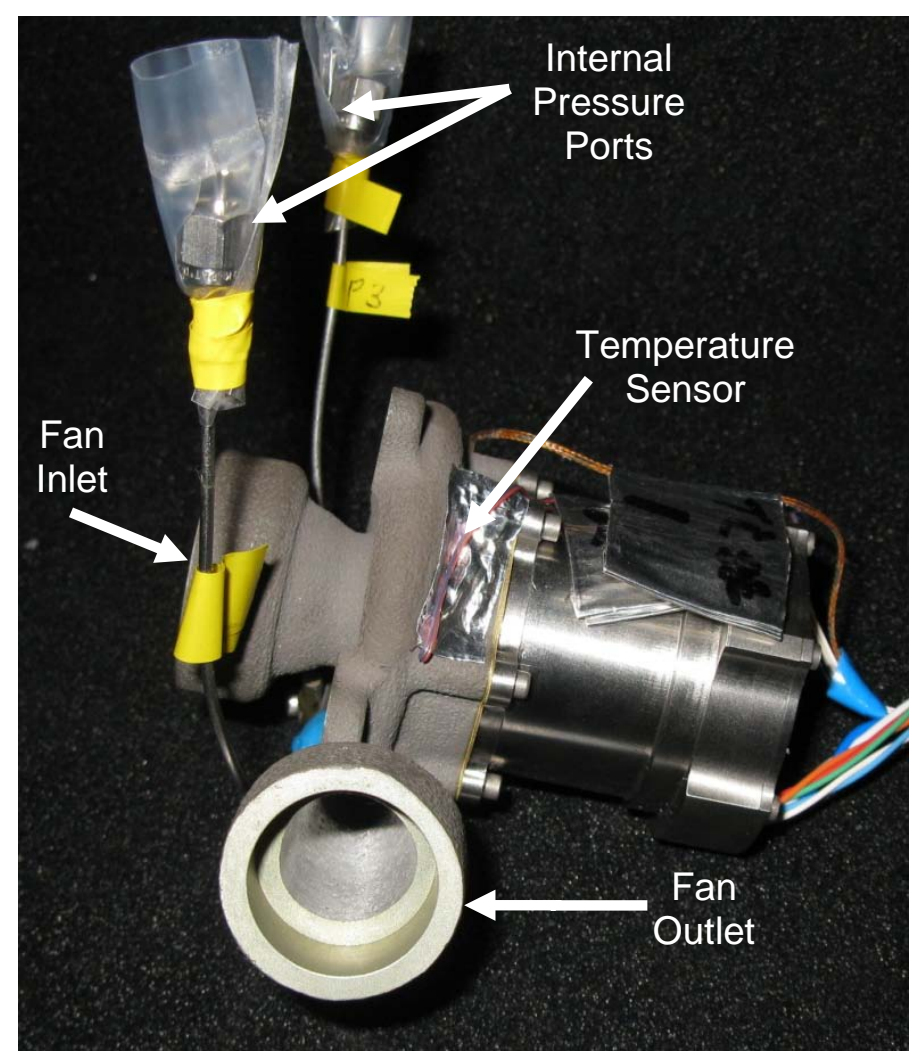

Figure 2: Photo of Fan Assembly 


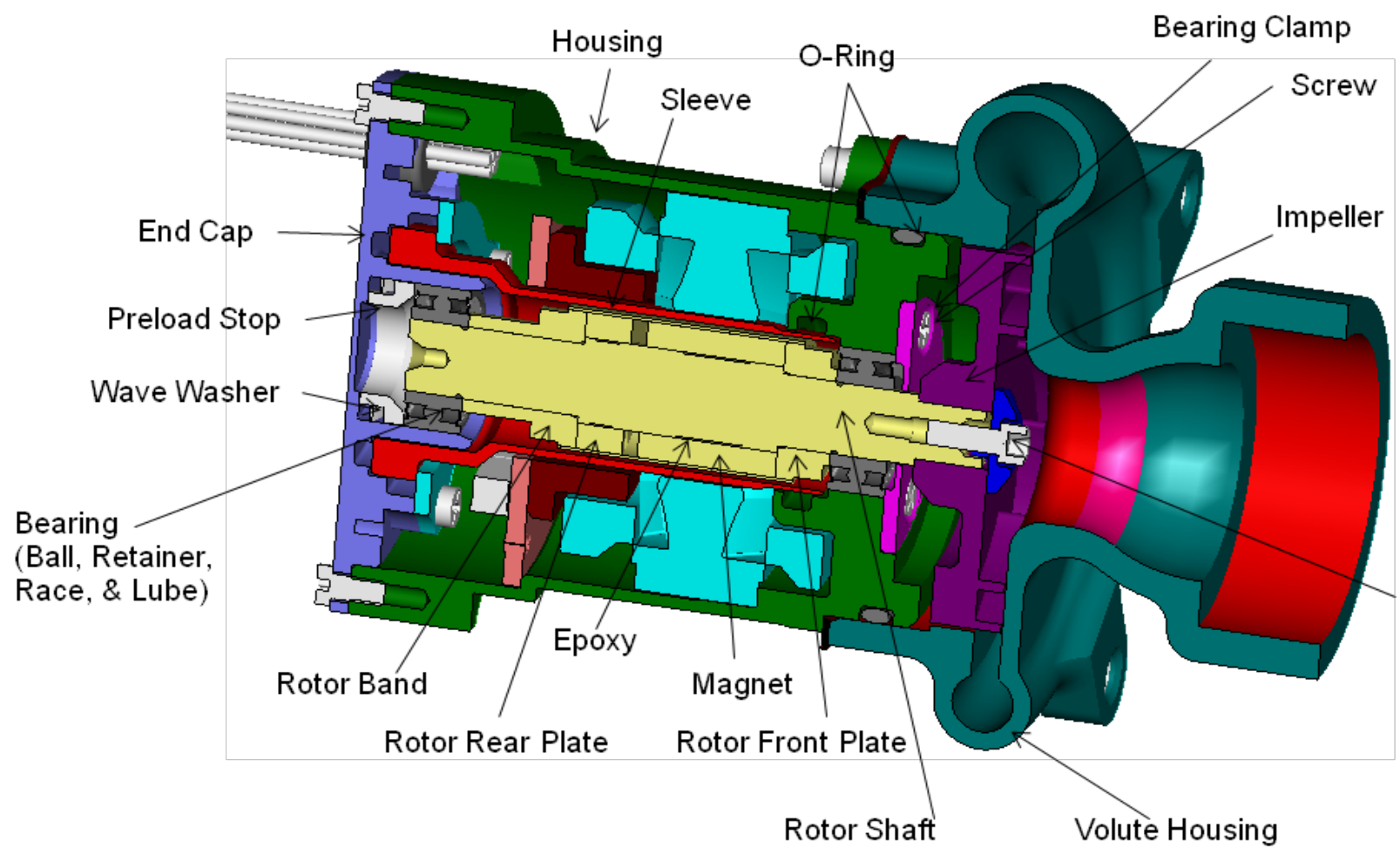

Figure 3: Fan Assembly Cross Section [2]

The motor of the development unit is contained inside a hermetically sealed nonmetallic can to prevent oxygen $\left(\mathrm{O}_{2}\right)$ gas from getting into the electric components. All materials were selected for $\mathrm{O}_{2}$ compatibility, although only air was used to test the development unit. The unit has two thermistors installed within the fan: one attached to the internal Hall Effect Device (HED) and the other installed on the stator.

\section{Fan Performance Testing}

\section{Test Objectives}

The test objectives for the Fan Performance Testing were based on the functional requirements for the next generation PLSS fan shown in Table 1. The design point (or nominal operation), maximum flow, and buddy mode requirements were also important points to characterize within this testing series.

Baseline performance testing conducted at the vendor location indicated that the fan operates at a nominal operating speed of approximately 39,400 revolutions per minute (rpm), at $51,400 \mathrm{rpm}$ for the maximum flow case, and at $72,700 \mathrm{rpm}$ to satisfy the buddy mode requirement. Therefore, the objectives for the performance testing were to test the fan development unit's performance by replicating the atmospheric pressure test results that the vendor performed and to fully characterize the fan at sub-atmospheric pressures. 


\section{Test Setup}

The testing was conducted in the PLSS Ventilation Laboratory, part of the Space Suit and Crew Survival Systems Branch, housed in room 2006 of JSC building 7.

During testing, the fan was installed into a test loop (Figure 4) constructed primarily with polyvinyl chloride (PVC) piping and hand valves [4]. Parts of the test loop were used by the vendor for the baseline performance testing and were delivered with the fan assembly to NASA [3]. The PVC piping was $3 / 4$ " in diameter and the full loop was approximately 14 feet in length. The fan and the test loop were connected using flexible hoses and small clamps. The test loop was controlled to the required pressure environments of 14.7 and 4.3 psia, verified by pressure data from sensors placed at tap points across the fan. For sub-ambient testing, the vacuum pump drew the system pressure down to the desired operating pressure through a needle valve (MV2). The valve was adjusted so that the vacuum balanced out the small leaks that were present in the loop to maintain the desired operating pressure throughout testing. The loop pressure drop was controlled using valve MV1. Closing the valve resulted in an increase in flow resistance which was used to raise the $\Delta \mathrm{P}$ in the loop and lower the flow rate. To measure the flow rate, a flow meter was located approximately 2 feet from the output of the fan. The speed of the fan was controlled using a potentiometer that was mounted to the front of the motor controller. Increasing the rpms resulted in the flow rate increasing and the $\Delta \mathrm{P}$ decreasing. The temperature inside the loop was monitored with a thermocouple (TC1). The temperature inside the fan motor was monitored at the stator, and the test was configured to shutdown if the stator reached a temperature over $160^{\circ}$ F. All testing was performed using room air as the operating fluid. All data was recorded on a Data Acquisition (DAQ) system. 


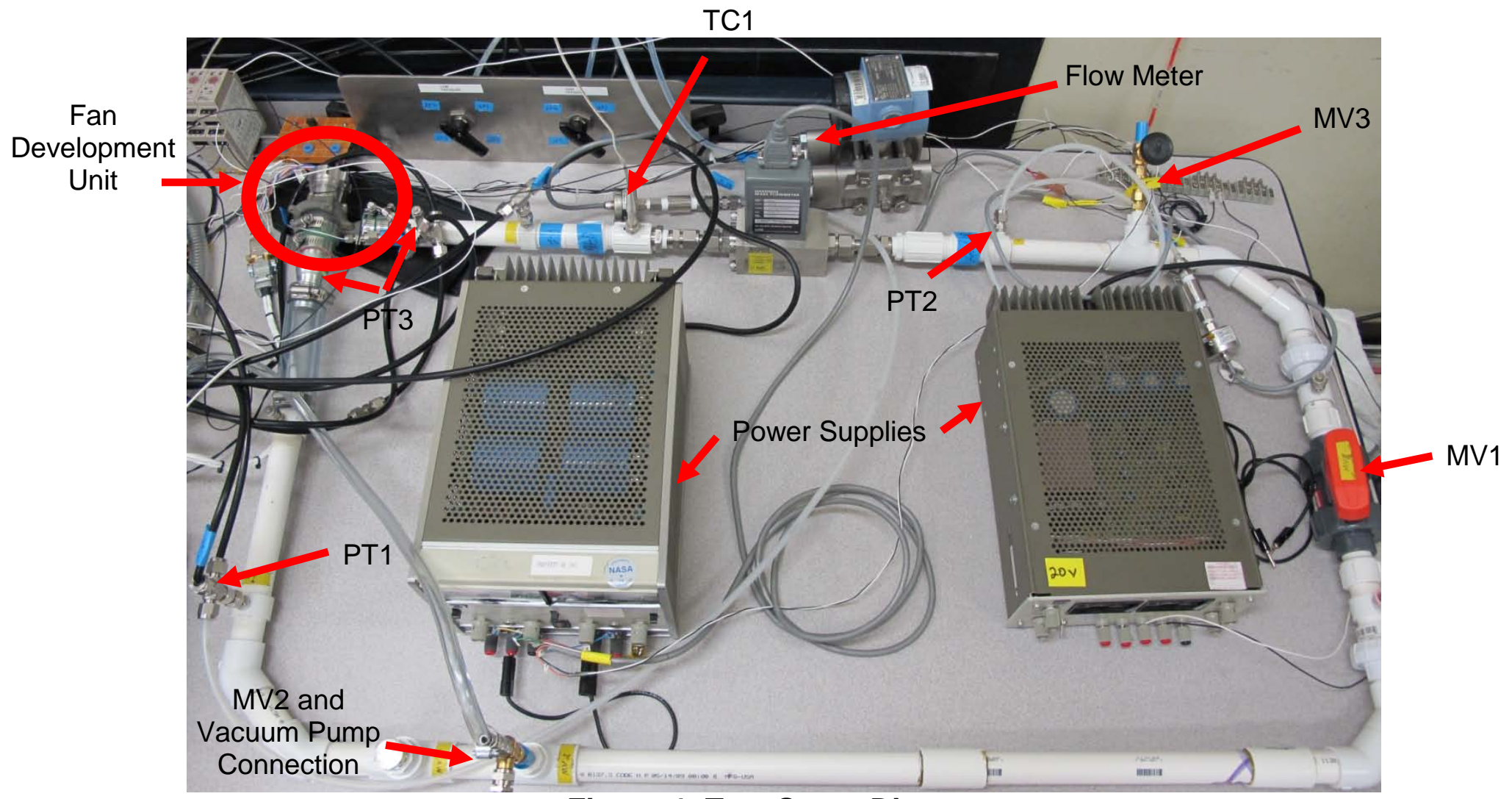

Figure 4: Test Setup Diagram

The following measurements were recorded during testing:

- Gas pressure at the inlet (psia) [PT1]

- Gas pressure at the outlet after the flow meter (psia) [PT2]

- Differential pressure across the fan (psid) [PT3]

- Gas flow rate (cfm)

- Fan speed (RPM)

- Full system power draw (V)

- Fan power draw (V)

- Temperature in the fan test loop $\left({ }^{\circ} \mathrm{F}\right)[\mathrm{TC} 1]$

- Temperature on the stator inside the fan $\left({ }^{\circ} \mathrm{F}\right)$

The data from the temperature in the fan test loop, the gas flow rate, and the loop pressure data were combined to give the actual cubic feet per minute (acfm), using Equation 1. The data from the pressure transducers and flow meter were adjusted using the calibration data from the NASA calibration lab, to scale the data correctly.

All power and voltage data was monitored using a Yokogawa WT500 power meter. During testing the power data was filtered using a $5500 \mathrm{~Hz}$ low pass filter. The power was monitored as it was supplied to the motor controller and as it was supplied to the fan motor. This allowed the power being used by the fan to be isolated from the power that was used by the motor controller. 
Data acquisition was controlled using LabVIEW Signal Express. The transducer and flow meter output was monitored using a NI-6052 DAQ. All data was recorded once every 12 seconds into space delimitated text files. The text files were opened in Microsoft Excel and graphed.

The PLSS Fan Test Loop was used with the associated test equipment listed in Table 2.

Table 2: PLSS Fan Test Loop Hardware List

\begin{tabular}{|c|c|c|c|}
\hline Component & Model Number & $\begin{array}{l}\text { Sketch } \\
\text { Identifier }\end{array}$ & Purpose/ Description \\
\hline Flow Meter & $\begin{array}{l}\text { Hastings STS- } \\
400 \mathrm{KK}\end{array}$ & FM-1 & Monitor the air flow rate in the loop \\
\hline Power Analyzer & Yokogawa WT500 & $\begin{array}{l}\text { Power } \\
\text { Analyzer }\end{array}$ & $\begin{array}{l}\text { Monitor the power input to the fan } \\
\text { and to the motor controller }\end{array}$ \\
\hline $\begin{array}{l}\text { Pressure } \\
\text { Transducers }\end{array}$ & $\begin{array}{l}\text { Omega Engineering } \\
\text { PX177-025Al }\end{array}$ & PT-1, PT-2 & $\begin{array}{l}\text { Monitor the pressure of the loop } \\
\text { upstream and downstream of the } \\
\text { test article }\end{array}$ \\
\hline $\begin{array}{l}\Delta \text { Pressure } \\
\text { Transducer }\end{array}$ & $\begin{array}{l}\text { Omega Engineering } \\
\text { PX760-100WCDI }\end{array}$ & PT-3 & $\begin{array}{l}\text { Monitor the pressure of the loop } \\
\text { across the test article }\end{array}$ \\
\hline $\begin{array}{l}\text { Data Acquisition } \\
\text { Unit }\end{array}$ & NI-6052E & & Record all test data \\
\hline $\begin{array}{l}\text { DAQ Breakout } \\
\text { Box }\end{array}$ & NI CP-50L & $\begin{array}{l}\text { DAQ } \\
\text { Breakout } \\
\text { Box }\end{array}$ & Connect DAQ to Test Equipment \\
\hline Thermistor & 311-P-18-07-A-76R & TM-1 & Monitor temperature inside of fan \\
\hline Thermocouple & Type K & TC-1 & Monitor temperature inside the loop \\
\hline Humidity Monitor & $\begin{array}{l}\text { Omega Engineering } \\
\text { OM-CP-PRH }\end{array}$ & & Monitor room humidity \\
\hline
\end{tabular}

Test Procedures

Each of the design points was first tested by setting the expected speed using the controls on the motor controller box and recording the steady state data after approximately one minute. Second, MV1 and the fan speed were adjusted to reach the desired delta pressure and flow rate, and steady state data were again recorded. These procedures were completed for the design point, maximum flow, and buddy mode cases at both 14.7 psia and 4.3 psia.

To collect data for the fan performance profile, the fan speed was set to 35,000 rpm and the flow control valve (MV1) was opened completely. After approximately one minute, data were collected. The flow rate was decreased by $10 \%$ increments until the fan was deadheaded, with data collected at each interval. MV1 was then opened completely and these steps were repeated for fan speeds of 40,000,50,000,60,000,70,000, and $75,000 \mathrm{rpm}$. The resulting data points were plotted to create a full profile of the fan's performance. This test was also performed at both 14.7 psia and 4.3 psia. 
Results

The flow meter output was translated from standard cubic feet per minute (scfm) to actual cubic feet per minute $(\mathrm{acfm})$ per Equation 1:

$$
a c f m=s c f m\left[\frac{\text { Pstd }}{(\text { Pact }- \text { Psat } \Phi)}\right]\left(\frac{\text { Tact }}{\text { Tstd }}\right)
$$

$\mathrm{P}_{\text {std }}=$ standard pressure in psia (14.7 psia)

$P_{\text {act }}=$ pressure at the flow meter in psia

$P_{\text {sat }}=$ saturation vapor pressure in psia

$\Phi=$ relative humidity

$\mathrm{T}_{\text {act }}=$ =temperature in the loop in ${ }^{0} \mathrm{R}$

$\mathrm{T}_{\text {std }}=$ standard temperature in ${ }^{\circ} \mathrm{R}\left(530{ }^{\circ} \mathrm{R}\right)$

$P_{\text {sat }}$ was calculated using Equation 2. This result was in millibars and was converted to psia.

$$
\text { Psat }=\exp \left(20.386-\frac{5132}{\text { temperature in loop (Temp2)in Kelvin }}\right)
$$

$P_{\text {act }}$ was calculated using Equation 3:

$$
\text { Pact }=(P T 1+P T 2+P T 3) / 2)
$$

These formulas were inserted into Equation 1. Equation 4 was entered into the Signal Express software.

$$
\begin{aligned}
\text { acfm } m=\operatorname{scfm} & ((14.7 /(((((P T 2+P T 1+P T 3) / 2)-(\exp (20.386-5132 /((T e m p 2 \\
& +459.67) *(5 / 9))) * 0.019336772)(\Phi)))))((T e m p 2+460) / 530))
\end{aligned}
$$

The value of $\Phi$ was recorded from a calibrated humidity monitor and entered at the beginning of each test.

\section{Performance Results at 14.7 psia}

The fan development unit was first tested at 14.7 psia in order to valid the test setup and the baseline data collected at the vendor, as well as insure that the test article had not sustained any damage in transport to JSC. The fan performance is plotted on Figure 5. The power usage of the fan/motor was graphed in Figure 6. Figure 7 shows the fan outlet temperatures that were recorded during this test.

Figure 5 shows the performance data for the three operating conditions and the performance curves. The design and maximum flow points are both slightly above the 
40,000 and 50,000 rpm curves. At $14.7 \mathrm{psia}$, the design point was achieved at 41,150 rpm and although that is higher than the baseline performance testing at the vendor, it is still in line with what is expected of the development unit. The Maximum Flow and Buddy Mode points also compared well to the data collected by the vendor. Additionally, each of the performance curves matches the baseline data. Overall the fan development unit is able to achieve the flow rate and delta pressure requirements, as described in Table 1 and performance testing proved that the test setup was adequate.

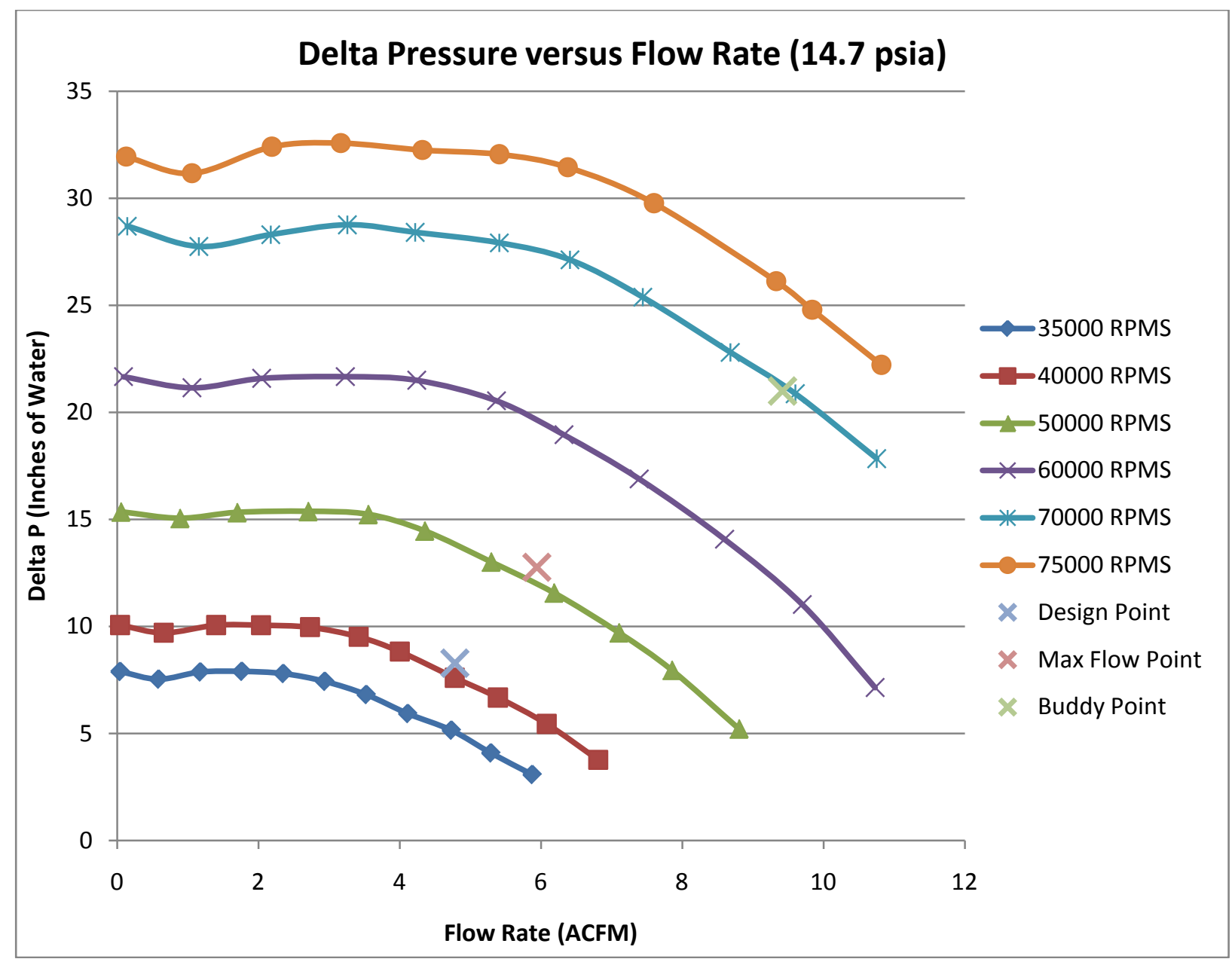

Figure 5: PLSS Fan Development Unit Profile at 14.7 psia

The fan power usage data was collected during the 14.7 psia testing and can be seen in Figure 6. As you can see the power increases with an increased flow rate and escalates significantly when running the development unit at a higher speed. This data is only shown for $35,000,40,000$, and 50,000 rpms because of an issue with the Yokagawa power analyzer. More information on this can be found in the Discussion section for the performance testing. 


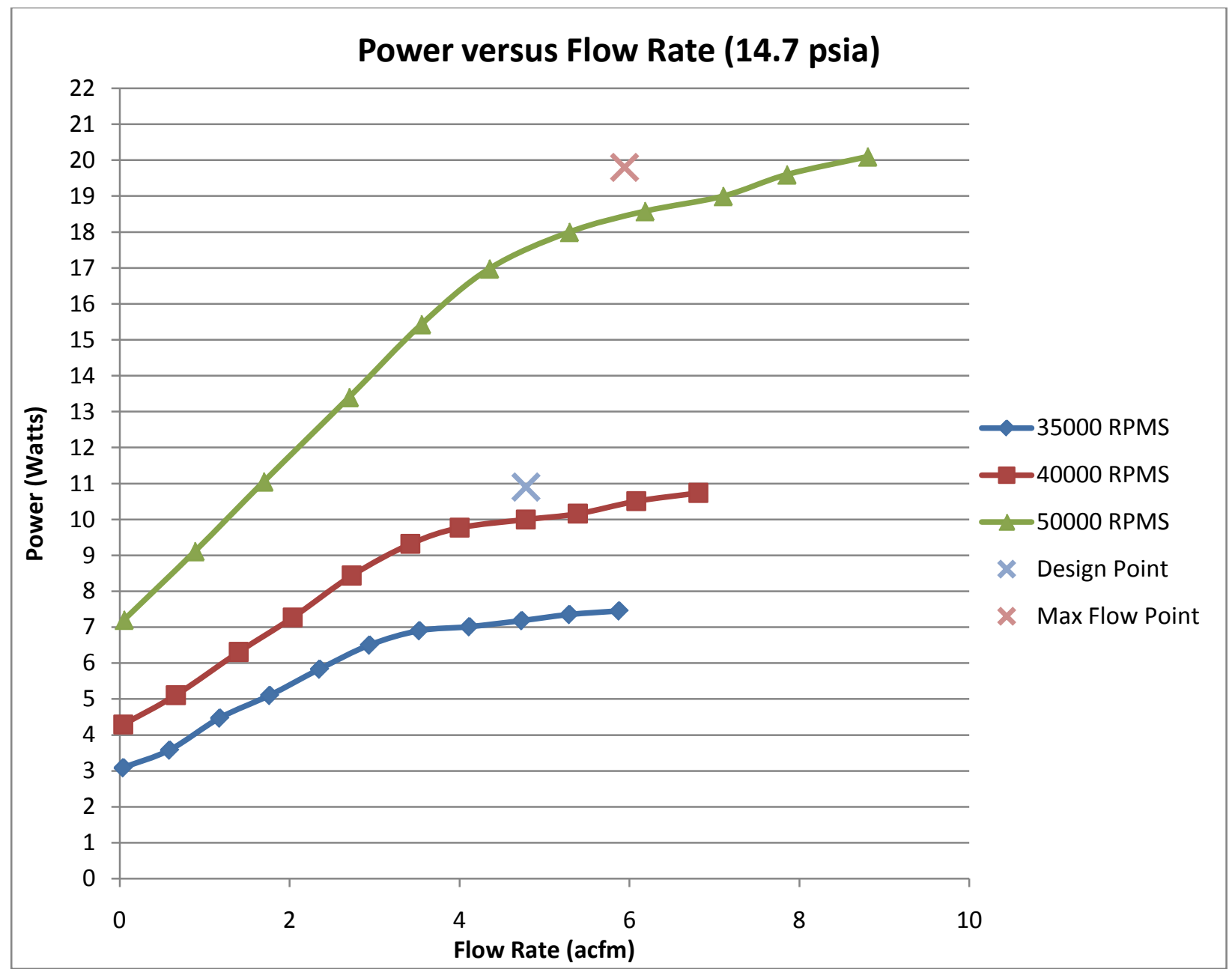

Figure 6: PLSS Fan Development Unit Power Usage vs Flow Rate at 14.7 psia

Fan outlet temperature was not something specifically reported by the vendor during baseline testing, but it is an important consideration for system-level life support development, as the heat generated by the fan increases the temperature of the ventilation loop, and therefore the ventilation loop may need to be conditioned to meet helmet inlet temperature requirements. Figure 7 shows the fan outlet temperature results. 


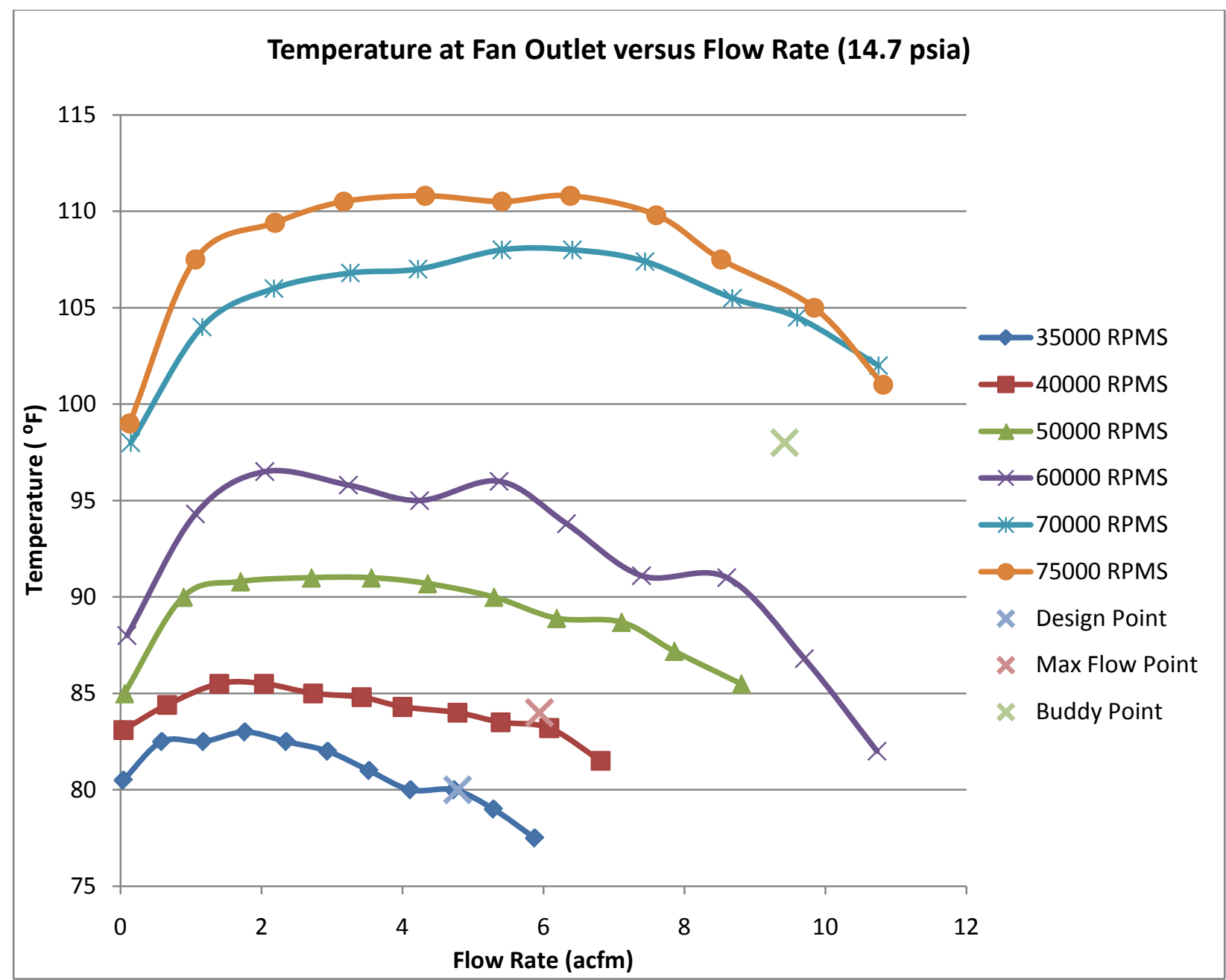

Figure 7: PLSS Fan Development Unit Output Air Temperature vs Flow Rate at 14.7 psia

Performance Results for 4.3 psia

Performance testing was conducted at 4.3 psia to characterize the performance in the anticipated space suit pressure environment. The results are plotted in Figure 8. The power usage of the fan alone is graphed in Figure 9. The fan outlet temperatures that were recorded during this test are graphed in Figure 10.

Compared to $14.7 \mathrm{psia}$, the delta pressure and flow rate data for $4.3 \mathrm{psia}$, is reduced significantly as expected with a reduction in test loop pressure. The design point falls on the 40,000 rpm line, which is near where the design point fell for the ambient test. Both the maximum flow point and buddy mode point also fell on the 50,000 and 70,000 rpms lines, respectively, similar to the 14.7 psia testing(Figure 8). Overall, the fan performance at $4.3 \mathrm{psia}$ is on par with the other performance data, and meets the requirements for the fan development unit. 


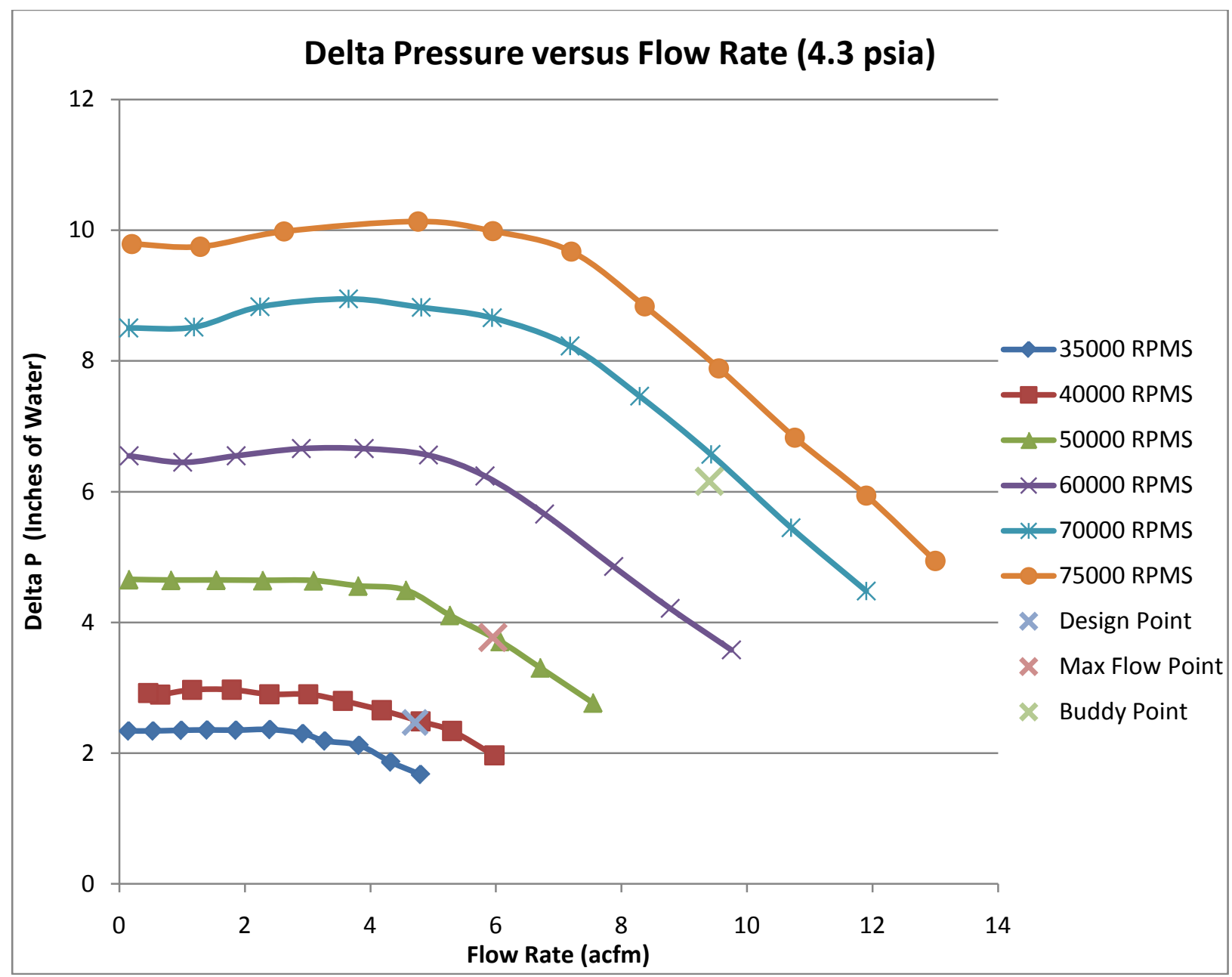

Figure 8: PLSS Fan Development Unit Performance Profile at 4.3 psia

Figure 9 shows the fan power usage for each performance point, including the three design points. At the design point, the power is $4 \mathrm{~W}$ which is under the $6 \mathrm{~W}$ requirement (Table 1). The maximum flow and buddy mode power usage are within a range of approximately 7.4 to $17 \mathrm{~W}$. Although no specific requirements are set for Fan/Motor power consumption for the off-nominal design points (maximum flow and buddy mode), these power usage values are as expected. 


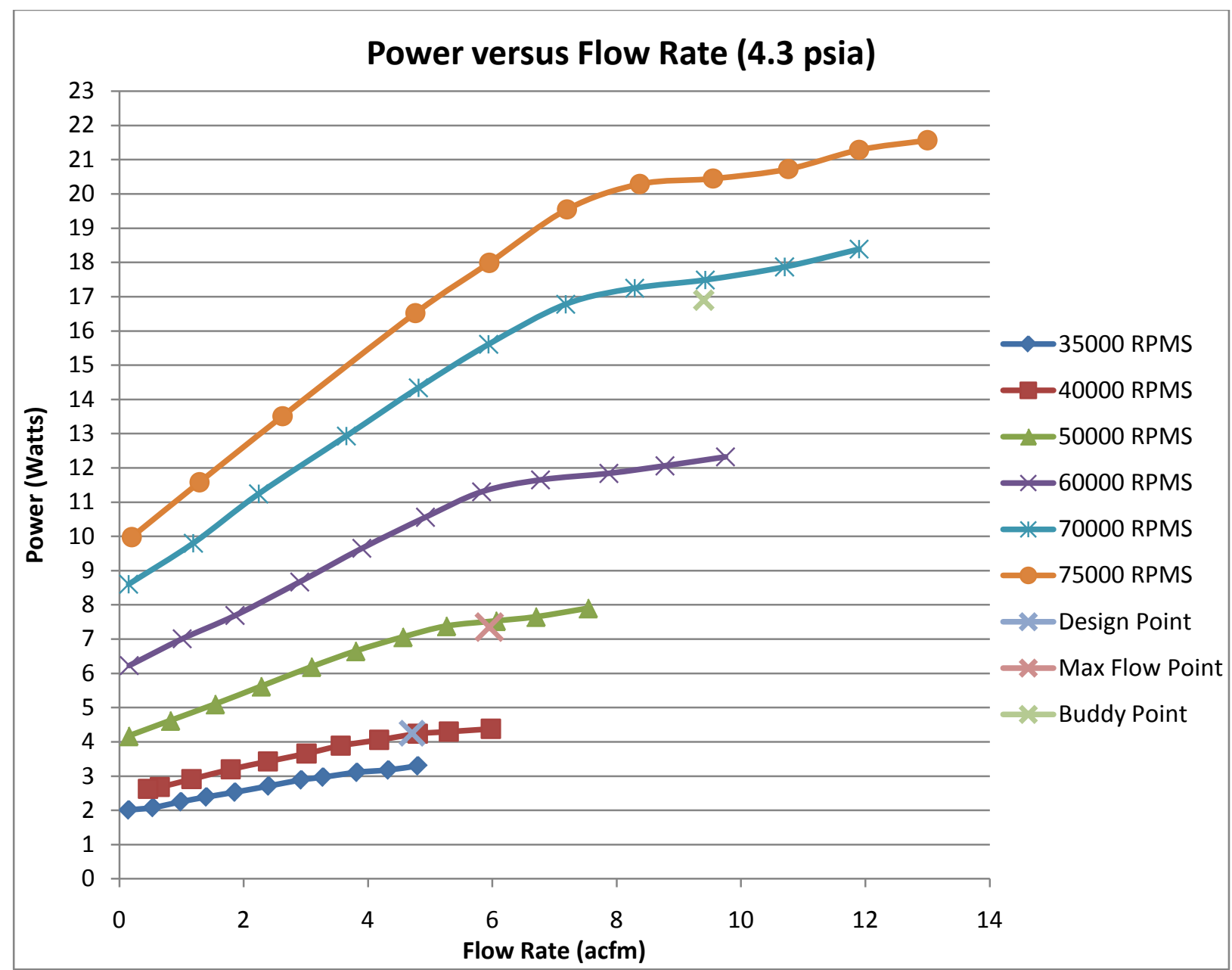

Figure 9: PLSS Fan Development Unit Power Usage vs Flow Rate at 4.3 psia

Figure 10 shows the outlet temperatures of the fan during sub-ambient testing at 4.3 psia. The three design points and each of the performance curves show that the fan adds as little as $10^{\circ} \mathrm{F}$ at the design point and as much as $20^{\circ} \mathrm{F}$ at the buddy mode case. 


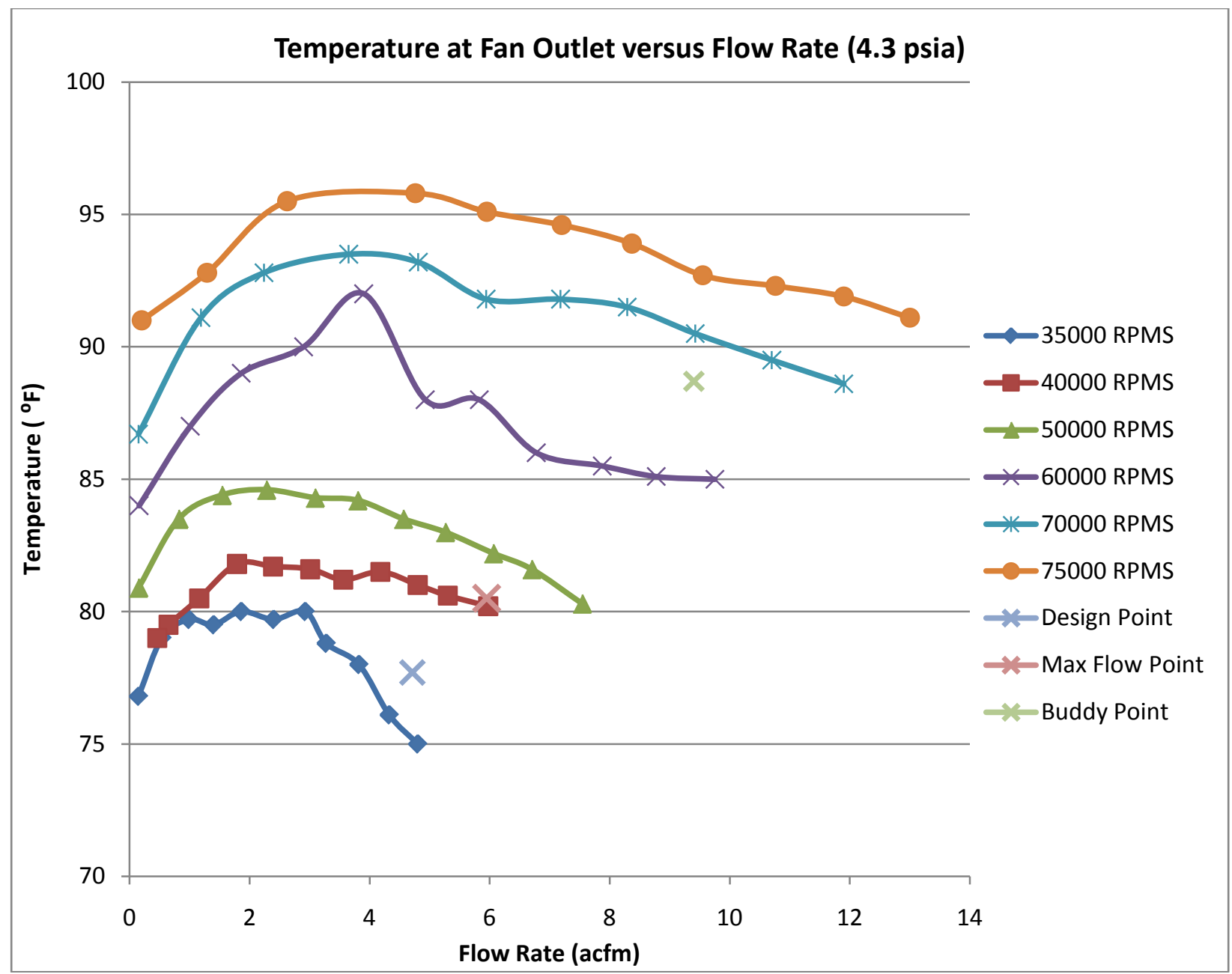

Figure 10: PLSS Fan Development Unit Outlet Air Temperature vs Flow Rate at 4.3 psia

A summary of the results for the ambient (14.7 psia) and the sub-ambient (4.3 psia) test pressures can be found in Table 3 . This table shows that although the delta pressure and the fan power decrease with the decrease in test pressure, the flow rate (acfm) and the fan speed (rpms) remain fairly constant. The table also has an adjusted delta pressure column that shows the delta pressure corrected for use in an oxygen loop as opposed to air.

Table 3: Design Point Test Results

\begin{tabular}{|ccccccc|}
\hline Test Description & $\begin{array}{c}\text { Delta } \\
\text { Pressure }\end{array}$ & acfm & $\begin{array}{c}\text { Fan } \\
\text { Power }\end{array}$ & $\begin{array}{c}\text { Outlet } \\
\text { Temp }\end{array}$ & $\begin{array}{c}\text { Adjusted } \\
\text { Delta } \\
\text { Pressure }\end{array}$ & rpms \\
\hline $\begin{array}{c}\text { Design Point @ } \\
\text { 14.7 psia }\end{array}$ & 8.29 & 4.78 & 10.9 & 80 & 8.45 & 41150 \\
\hline Max Point @ & 12.77 & 5.94 & 19.8 & 84 & 13.11 & 51100 \\
\hline
\end{tabular}




\begin{tabular}{|ccccccc|}
\hline 14.7 psia & & & & & & \\
\hline $\begin{array}{c}\text { Buddy Point @ } \\
\text { 14.7 psia }\end{array}$ & 21 & 9.42 & 48.7 & 98 & 22.11 & 70162 \\
\hline $\begin{array}{c}\text { Design Point @ } \\
\text { 4.3 psia }\end{array}$ & 2.47 & 4.71 & 4.25 & 77.7 & 2.47 & 39452 \\
\hline $\begin{array}{c}\text { Max Point @ 4.3 } \\
\text { psia }\end{array}$ & 3.77 & 5.95 & 7.35 & 80.5 & 3.77 & 49402 \\
\hline $\begin{array}{c}\text { Buddy Point @ } \\
\text { 4.3 psia }\end{array}$ & 6.16 & 9.4 & 16.9 & 88.7 & 6.16 & 68540 \\
\hline
\end{tabular}

\section{Discussion}

There were several issues that occurred during the ambient pressure fan profile testing. The first was that the flow meter that was originally planned to be used for all fan testing was found to have too great of a pressure delta across it to meet the requirements for testing. The replacement flow meter had a maximum calibrated flow measurement rate of $10 \mathrm{scfm}$. This rate was lower than the fan's maximum flow output when the fan was set to 70,000 and 75,000 rpms with the flow control valve fully opened at 14.7 PSIA. This made it impossible to follow the original test plan and the test was performed using the maximum flow that the flow meter would support (10 scfm) as the starting flow rate instead during ambient pressure testing. For this reason, the fan performance curves at 14.7 PSIA do not extend out past approximately $10 \mathrm{acfm}$ even though the fan is capable of delivering those flow rates.

The second issue was that the power analyzer stopped operating correctly after the 50,000 RPM ambient pressure profile test. For this reason, there is no fan power data available from the $60,000,70,000$, and $75,000 \mathrm{rpm}$ tests. The second voltage channel failed, which made it impossible to monitor the power use of the fan. However, this did not affect the ability of the power meter to record the power usage of the motor controller, as the motor controller power measurement only used the first channel of the power meter. For this reason, only the motor controller power usage is recorded. The power meter was sent out for repair and a fully operational replacement unit was used for the final 5 days of performance testing and for the duration of the life cycle testing.

The third issue was that the fan rpm rate became unstable at several of the higher rpm speeds. This may have been caused by the fan not receiving enough air to output a consistent flow, by resonant points in the pressure loop, or by some other issue with the motor controller. This behavior was only seen in the ambient pressure testing and so is not a major concern. The oscillations were seen at $70,000 \mathrm{rpms}$ with a flow rate of 4.22 acfm, 75,000 rpms with a flow rate of $2.19 \mathrm{acfm}$, and 75,000 rpms with a flow rate of $1.06 \mathrm{acfm}$.

The final issue was the high temperatures experienced during 14.7 psia testing. The fan development unit was designed for sub-ambient operation, therefore testing at 
ambient pressure resulted in high test loop temperatures. Similar temperatures were not encountered during 4.3 psia testing, however this was possibly due to some level of leakage into the test loop that conditioned the gas temperature.

To correct for the high test loop temperatures experienced during ambient testing, inlet temperature was adjusted to $70^{\circ} \mathrm{F}$ to match the inlet temperatures encountered during sub-ambient (4.3 psia) testing. Ambient delta pressure values were scaled using Equation 4 and a temperature standard of $70^{\circ} \mathrm{F}$. The normalized data is graphed in Figure 11.

temperature adjustment factor $=\frac{((\text { the test temperature })+460)}{((\text { the temperature standard })+460)}$

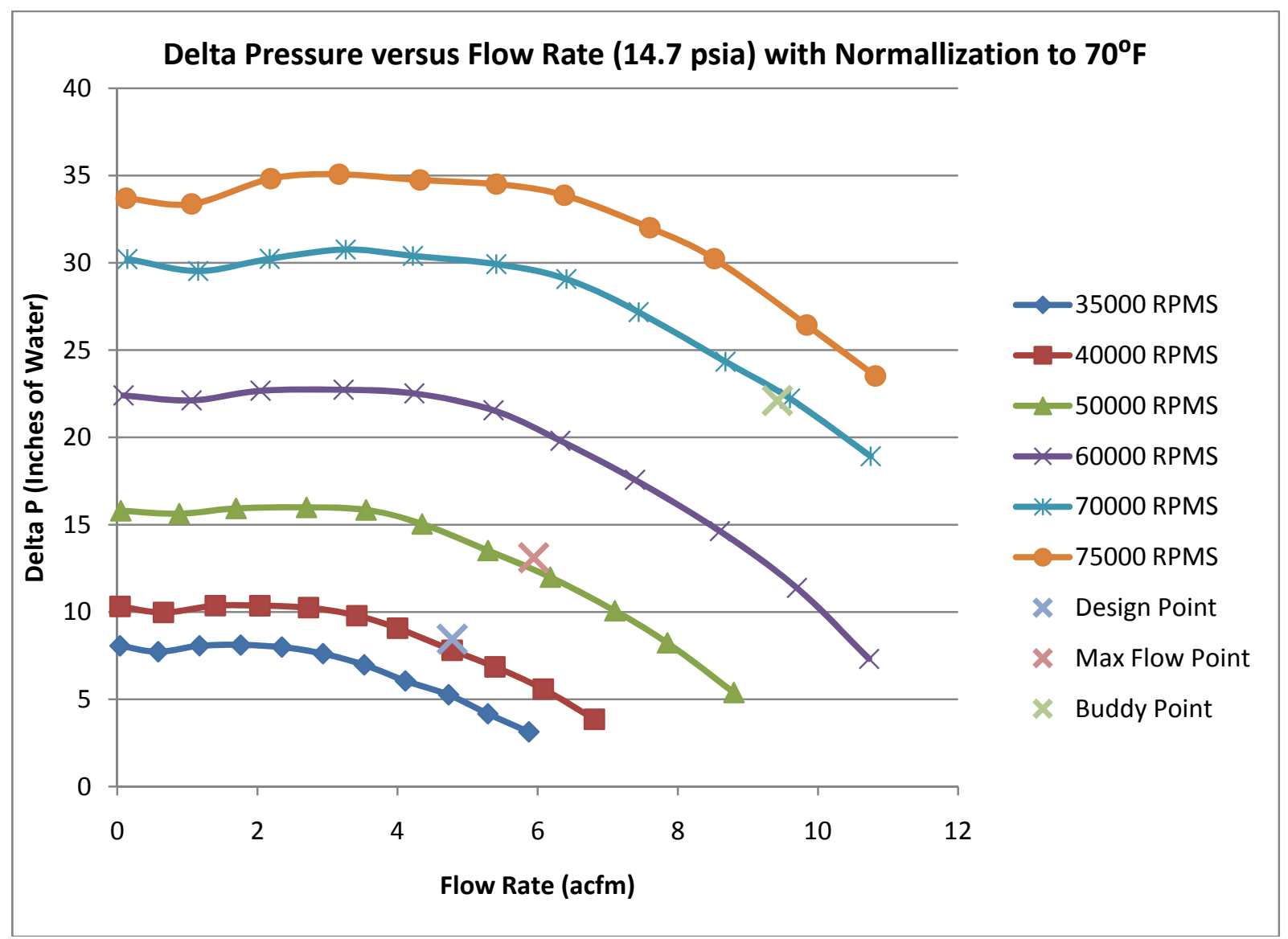

Figure 11: PLSS Fan Development Unit Profile at 14.7 psia with Temperature Normalization

As shown in Figure 12, the fan performed almost exactly as it was projected at 14.7 psia based on the 4.3 psia results. The only major deviation occurred at the high flow end of the 35,000 and $40,000 \mathrm{rpm}$ tests. This deviation was also seen in the initial design point test. These minor differences only reached a maximum of about $0.5 \mathrm{acfm}$. In total, the 4.3 psia fan performance results were consistent with the 14.7 psia results. 


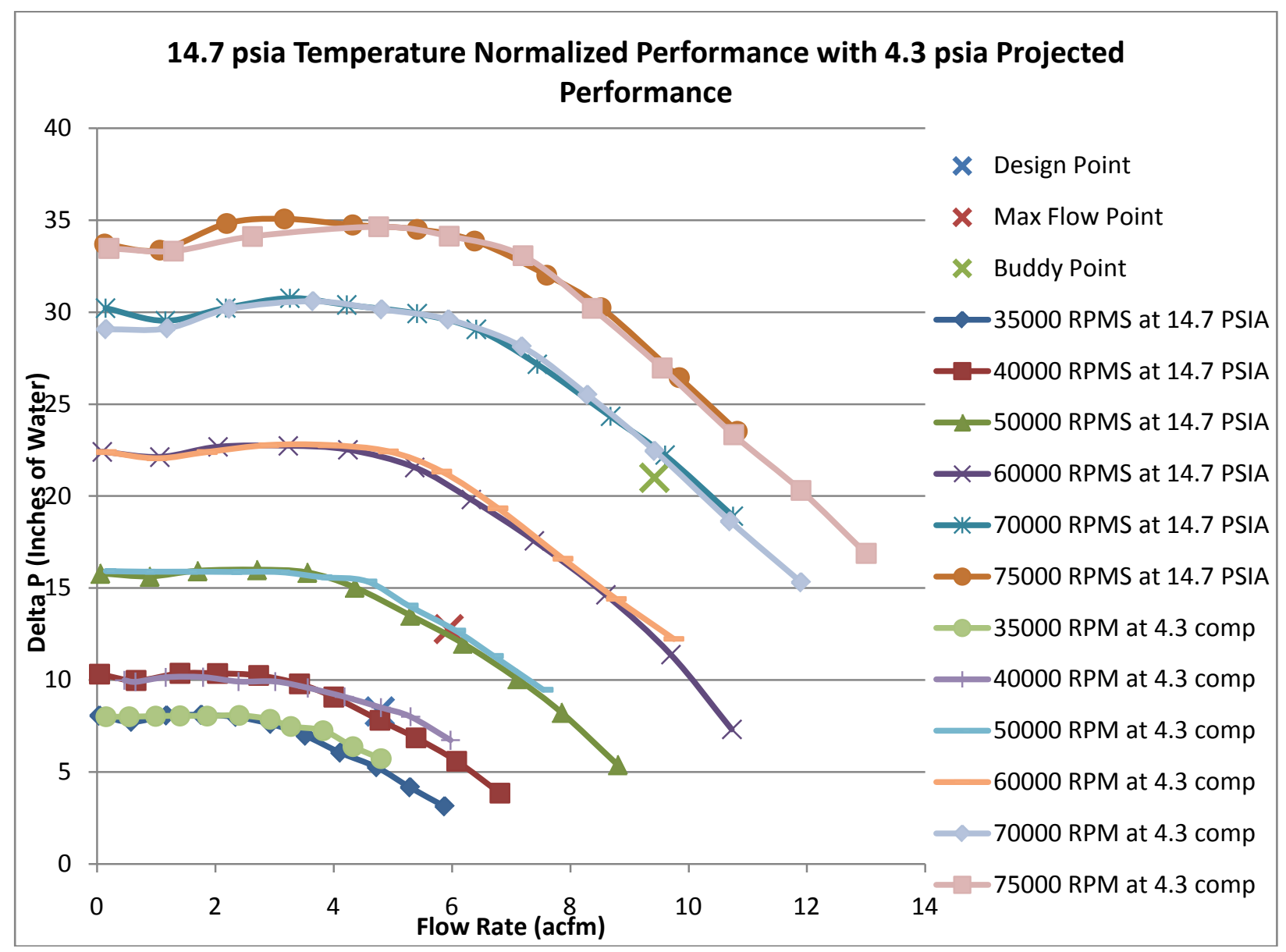

Figure 12: 14.7 psia Fan Performance with 4.3 psia Performance Adjusted to 14.7 psia

It proved to be difficult to perfectly match the settings that were used during the baseline performance testing because the flow control valve and rpm potentiometer had low degrees of resolution. For this reason, all delta pressure and acfm targets were given a tolerance of \pm 0.1 and all rpm targets were given a tolerance of $\pm 250 \mathrm{rpms}$.

\section{Life Cycle Testing}

Test Objectives

The test objectives for the Life Cycle Testing were to simulate the life of the fan, by continuously running the unit for about 30 days and observing any performance degradation.

Test Setup 
The testing was conducted in the PLSS Ventilation Laboratory, part of the Space Suit and Crew Survival Systems Branch, housed in room 2006 of JSC building 7.

The PVC test loop and all associated instrumentation was used for this testing, in the same configuration as shown in Figure 4 for the Fan Performance Testing. Room air was again used as the operating fluid, and all data was recorded on a Data Acquisition (DAQ) system.

\section{Test Procedures}

The test loop was initially configured for the nominal design point condition: 39,400 \pm $250 \mathrm{rpm}, 2.7 \pm 0.1$ inches of water for the delta pressure, and a flow rate below $4.7 \mathrm{cfm}$, while the test loop was operated at $4.3 \pm 0.1 \mathrm{psia}$. Then the loop was allowed to run continuously for approximately 30 days. During this time, the test loop was checked twice a day to ensure that the test loop and fan were still operating and that the data was still within the tolerances allowed.

\section{Results}

Figure 13 shows the fan data during the 740 hours of testing. The rpm values are shown on the right axis and all other signal (loop pressure, delta pressure, and flow rate) share the left axis. As you can see, the loop and delta pressure remained constant during the duration of the testing. The flow rate fluctuated slightly during the second half of testing. Fan speed however, began to oscillate at approximately the 570 hours into the test. These and other anomalies are discussed in the Life Cycle Discussion section. 


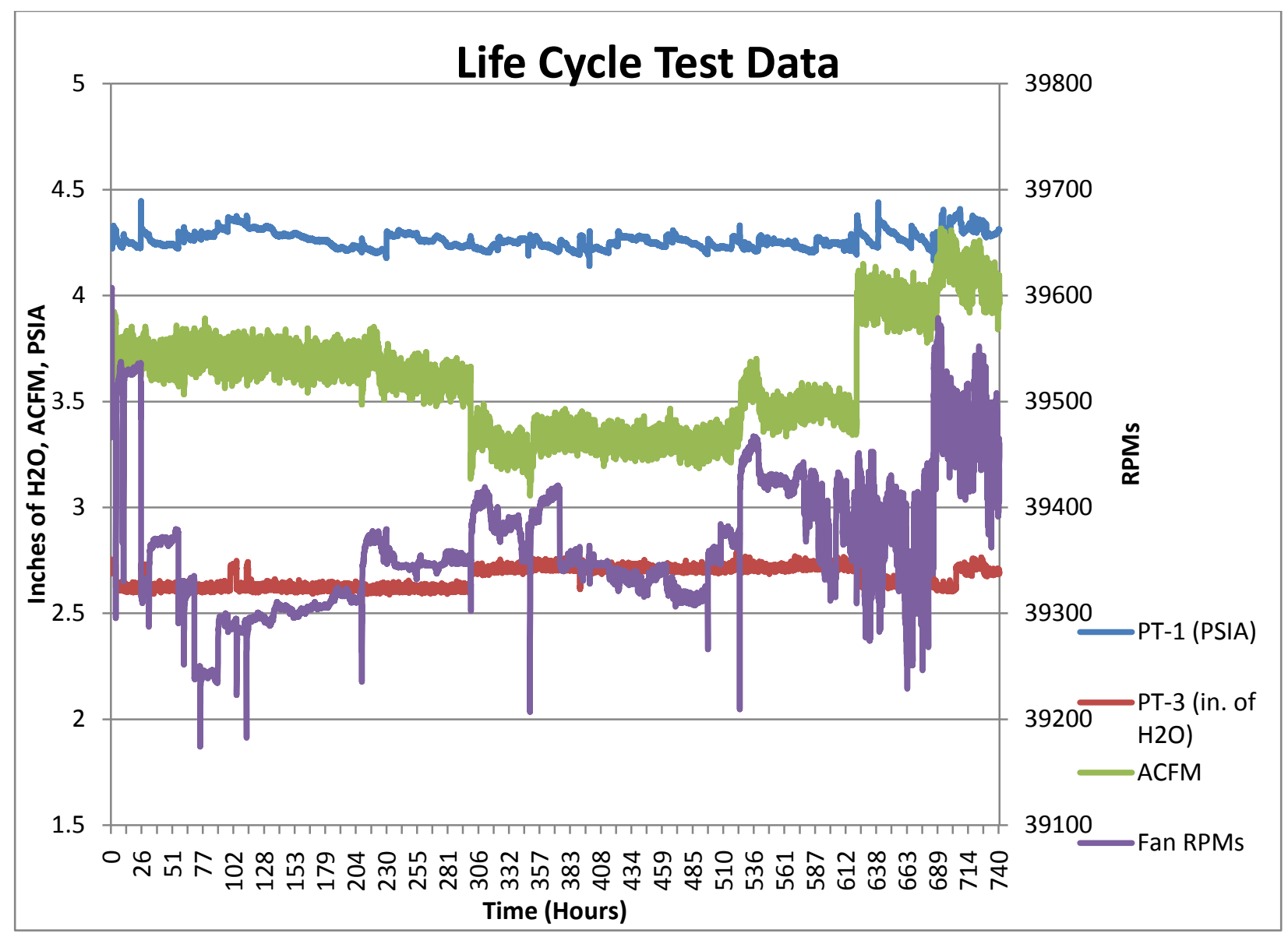

Figure 13: PLSS Fan Development Unit Life Cycle Results at 4.3 psia

Table 4 shows a test point from early in the testing and late in the testing. The data shows that the fan performance overall did not change throughout the test. In total the fan was tested for approximately 740 hours at the nominal operating conditions for the fan, and performed as expected.

Table 4: Life Cycle Test Results

\begin{tabular}{|c|c|c|c|c|c|c|}
\hline Test Description & Delta P & acfm & $\begin{array}{c}\text { MC } \\
\text { Power }\end{array}$ & $\begin{array}{l}\text { Outlet } \\
\text { Temp }\end{array}$ & rpms & $\begin{array}{c}\text { Inlet } \\
\text { Pressure }\end{array}$ \\
\hline Initial Test Output & 2.73 & 3.80 & 10.27 & 80.1 & 39498 & 4.25 \\
\hline Final Test Output & 2.70 & 4.03 & 10.67 & 84.8 & 39436 & 4.37 \\
\hline
\end{tabular}

Discussion

During testing, the loop pressure tended to drift downwards over extended periods. On two occasions this was not noticed until after the fan had run for significant amounts of time at below the minimum input pressure of 4.2 PSIA. The run time from these periods was not counted toward the 740 hours of run time. The fan ran for an additional 140 hours while outside the target requirements. 
Based on Figure 13, two potential anomalies are apparent. The first, a drop in flow rate that can be seen in the Figure 14 graph below after approximately 300 hours of run time, can be attributed to increase in delta pressure that also occurred at that time. The delta pressure was adjusted from approximately 2.61 in. of $\mathrm{H}_{2} \mathrm{O}$ to 2.73 in. of $\mathrm{H}_{2} \mathrm{O}$. This caused a corresponding drop in flow rate. This adjustment was made because a delta pressure of 2.61 inches of water is near the low limit allowed for the test, so the delta pressure was adjusted closer to the target of 2.7 inches of water. At the point marked "POI" (Point Of Interest) in Figure 14, the flow rate increased briefly because the fan RPMs increased at that point. The flow rate increased once the delta pressure decreased and the fan RPMs increased at approximately the 625 hour mark. This general behavior is expected, a higher delta pressure indicates that there is greater impedance to air flow, so the airflow should be lower. Also, higher fan RPM rates will result in higher flow rates. In this case, the fan performed as expected throughout the testing.

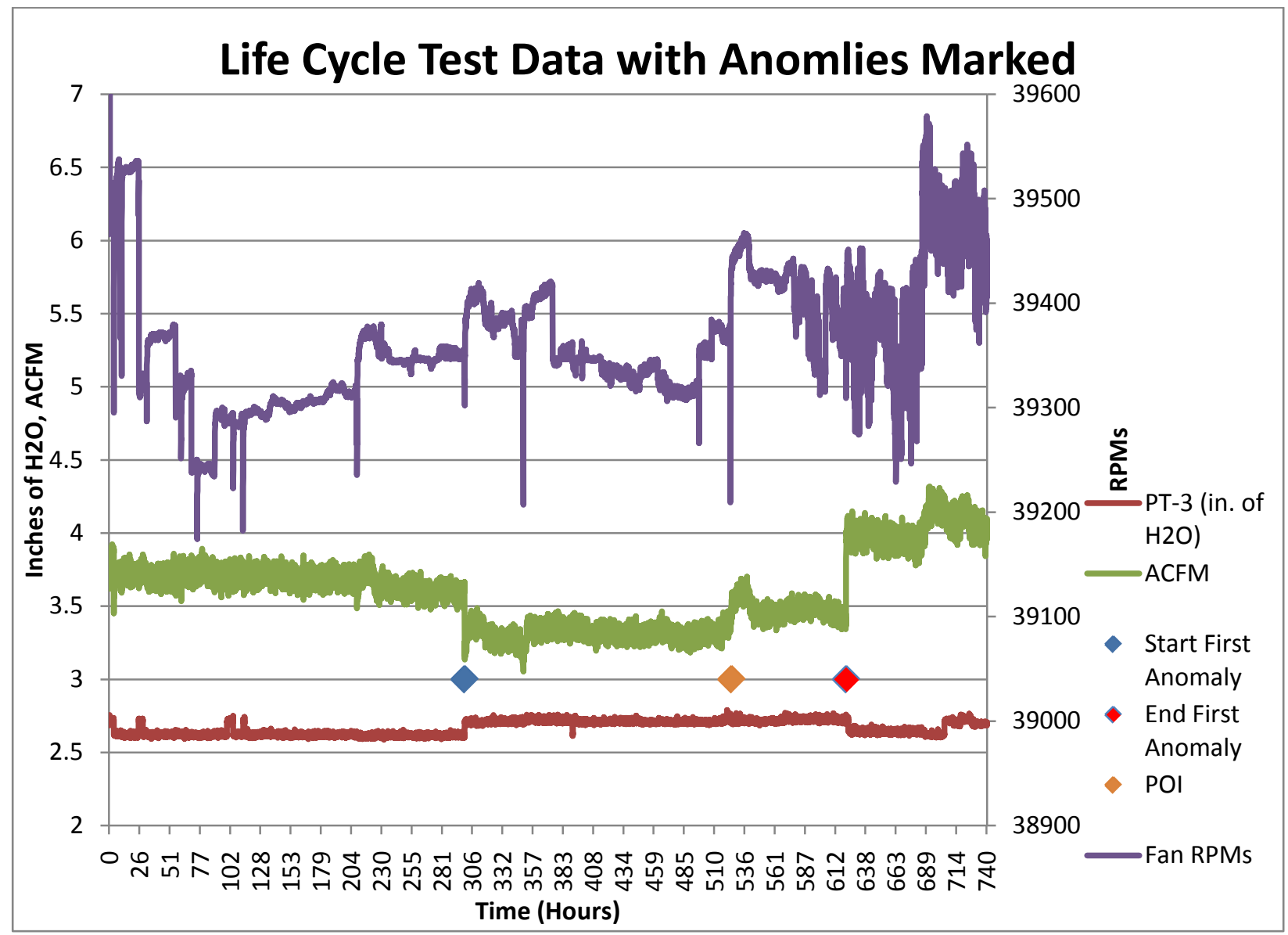

Figure 14: PLSS Fan Development Unit Life Cycle Results with First Anomly Marked 
The second potential anomaly was the general loss of stability in the fan RPM set point. This occurred at about the 575 hour mark. Figure 15 shows a red diamond on the graph represents the "second" anomaly, when the fan power also became unstable. The power values in watts are on the right axis and the RPMs are on the left axis. The instability of the motor controller input power implies that the fan RPM setting was actually unstable and the observed readings were not caused by some error in reading the RPM information. This issue was not a failure of the life cycle test because the RPM rates stayed within the $39404 \pm 250$ RPM window that the test requirements specified. Additionally, the fan continued to push air within the acceptable limits for the test. However, the instability of the RPM set point may be an early sign of a future degradation of fan performance.

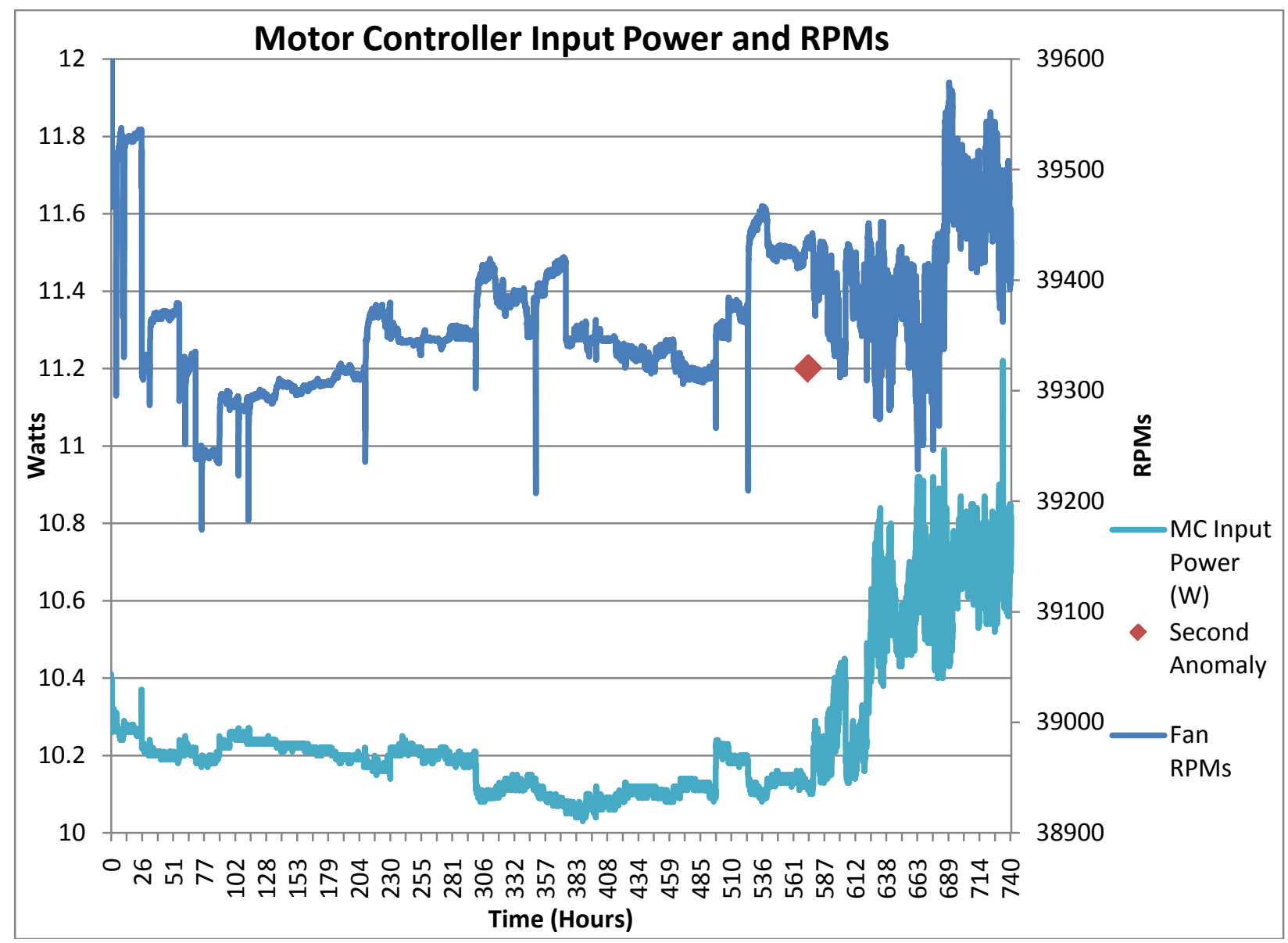

Figure 15: PLSS Fan Development Unit Motor Controller (MC) Power Usage and rpms at 4.3 psia

Possible causes of this anomaly include electromagnetic interference between the fan and motor controller, an issue with the motor controller, a problem with the fan position sensor, or a problem with the fan motor. It is not possible to determine the exact cause without further testing. 


\section{Oxygen Compatibility Assessment}

An oxygen compatibility assessment (OCA) was performed NASA's White Sands Test Facility (WSTF) to evaluate the fan assembly design and materials selection for use in an $\mathrm{O}_{2}$ environment. Both nominal and worst-case operating conditions were assessed. The materials were studied to determine the flammability or non-flammability of each. Finally, ignition mechanisms of the fan were determined (frictional heating, rapid pressurization, mechanical impact, particle impact, static discharge, electrical discharge, flow friction, chatter, and/or other ignition mechanisms). The following were recommendations provided to the PLSS development team [6] and/or by PLSS team members to minimize and/or eliminate the hazards associated with working in an oxygen system.

- Perform testing to determine the auto ignition temperature of the bearing grease

- Perform bearing tests under normal operation conditions to determine if the grease will ignite, and if there is a kindling chain present in the event of grease ignition

- Perform another test series to determine the effect of damaged bearings

- Perform standard and configuration friction tests at 25 psia to determine the possibility of frictional ignition. This testing could be a multi-phase testing program with increased fidelity of configuration as design details become more known.

- Additional recommendations include additional bearing and lubrication testing, materials testing for the motor magnet, and continued efforts to study tolerances and materials where components rub together within the fan.

Table 5 shows each component or material in the fan development unit, along with the material, material type, flammability, and notes/recommendations.

Table 5: Fan Development Unit Material Flammability

\begin{tabular}{|c|c|c|c|c|}
\hline Part & Category & Material & Flammability & Notes/Recommendations \\
\hline End Cap & Metal & $\begin{array}{c}303 \\
\text { Stainless } \\
\text { Steel }\end{array}$ & $\mathrm{N}$ & $\begin{array}{l}\text { No data exists for } 303 \text { stainless steel; however, } 300 \\
\text { series stainless steel is considered flammable in } \\
100 \% \text { oxygen at pressures above } 111 \text { psia (ASTM } \\
\text { MNL } 36,2 \text { nd. Ed., Table } 3-1 \text { ). Therefore, } 303 \\
\text { stainless steel is considered flammable under these } \\
\text { same conditions. }\end{array}$ \\
\hline Housing & Metal & $\begin{array}{c}303 \\
\text { Stainless } \\
\text { Steel }\end{array}$ & $\mathrm{N}$ & $\begin{array}{l}\text { No data exists for } 303 \text { stainless steel; however, } 300 \\
\text { series stainless steel is considered flammable in } \\
100 \% \text { oxygen at pressures above } 111 \text { psia (ASTM } \\
\text { MNL } 36,2 \text { nd. Ed., Table } 3-1 \text { ). Therefore, } 303 \\
\text { stainless steel is considered flammable under these } \\
\text { same conditions. }\end{array}$ \\
\hline Race & Metal & $\begin{array}{c}440 \mathrm{C} \\
\text { Stainless } \\
\text { Steel }\end{array}$ & $\mathrm{F}$ & $\begin{array}{l}\text { There is no flammability data for } 440 \mathrm{C} \text { stainless } \\
\text { steel. However, based on composition, } 400 \text { series } \\
\text { stainless steels are considered to be at least as } \\
\text { oxygen compatibile as } 300 \text { series stainless steels. } \\
300 \text { series stainless steel is considered flammable }\end{array}$ \\
\hline
\end{tabular}




\begin{tabular}{|c|c|c|c|c|}
\hline & & & & $\begin{array}{l}\text { in } 100 \% \text { oxygen at pressures above } 111 \text { psia } \\
\text { (WSTF 06-0375). However, thin cross sections of } \\
\text { stainless steel are flammable in } 100 \% \text { oxygen at } \\
\text { ambient pressure (ASTM Manual 36, 2nd Ed., } \\
\text { Tables 3-2 and 3-3). }\end{array}$ \\
\hline Screws & Metal & $\begin{array}{l}\text { A-286 } \\
\text { Stainless } \\
\text { Steel }\end{array}$ & $\mathrm{N}$ & $\begin{array}{l}\text { Material flammability data is not available for A-286 } \\
\text { stainless steel. However, its composition can be } \\
\text { compared to } 316 \text { stainless steel. A-286 stainless } \\
\text { steel is } 56 \% \text { iron, } 25 \% \text { nickel, and } 14.5 \% \text { chromium. } \\
316 \text { stainless steel is } 65 \% \text { iron, } 12 \% \text { nickel, and } \\
17 \% \text { chromium. Iron is not considered to be oxygen } \\
\text { compatible; however, nickel is very oxygen } \\
\text { compatible. A-286 stainless steel is composed of } \\
\text { less iron and more nickel than } 316 \text { stainless steel; } \\
\text { therefore, A-286 stainless steel can be considered } \\
\text { at least as oxygen compatible as } 316 \text { stainless } \\
\text { steel. } \\
300 \text { series stainless steel is considered flammable } \\
\text { in } 100 \% \text { oxygen at pressures above } 111 \text { psia } \\
\text { (ASTM MNL } 36,2 \text { nd. Ed., Table } 3-1 \text { ). Therefore, } \\
\text { the A-286 stainless steel parts are considered } \\
\text { nonflammable in } 100 \% \text { oxygen at } 25 \text { psia. }\end{array}$ \\
\hline $\begin{array}{l}\text { Wave } \\
\text { Spring }\end{array}$ & Metal & $\begin{array}{l}17-7 \mathrm{PH} \\
\text { Stainless } \\
\text { Steel }\end{array}$ & $F$ & $\begin{array}{l}\text { Material flammability data is not available for } 17-7 \\
\mathrm{PH} \text { stainless steel. } 17-4 \mathrm{PH} \text { stainless steel is similar } \\
\text { to } 17-7 \mathrm{PH} \text { and is flammable as a } 1 / 8 \text { in. rod in } \\
100 \% \text { oxygen at pressures above } 150 \text { psia (ASTM } \\
\text { STP } 1111, \text { pp. } 288-297 \text { ). There is no data available } \\
\text { for thin cross-sections of } 17-7 \mathrm{PH} \text { stainless steel. } \\
\text { Therefore, thin cross-sections of } 17-7 \mathrm{PH} \text { stainless } \\
\text { steel are considered flammable in } 100 \% \text { oxygen. }\end{array}$ \\
\hline $\begin{array}{l}\text { Rotor } \\
\text { Shaft }\end{array}$ & Metal & $\begin{array}{l}15-5 \mathrm{PH} \\
\text { Stainless } \\
\text { Steel }\end{array}$ & $\mathrm{N}$ & $\begin{array}{l}15-5 \mathrm{PH} \text { stainless steel is flammable as an } 1 / 8 " \text { rod } \\
\text { in } 100 \% \text { oxygen at pressures above } 150 \text { psia. } \\
\text { (WSTF \# 07-41720). }\end{array}$ \\
\hline Washer & Metal & $\begin{array}{l}17-4 \mathrm{PH} \\
\text { or } 15-5 \\
\text { PH } \\
\text { Stainless } \\
\text { Steel }\end{array}$ & $\mathrm{F}$ & $\begin{array}{l}\text { There is no data available for thin cross sections of } \\
17-4 \mathrm{PH} \text { or } 15-5 \mathrm{PH} \text { stainless steel. Therefore, thin } \\
\text { cross-sections of } 17-4 \text { or } 15-5 \mathrm{PH} \text { are considered } \\
\text { flammable in } 100 \% \text { oxygen at ambient pressure. }\end{array}$ \\
\hline $\begin{array}{l}\text { Preload } \\
\text { Stop }\end{array}$ & Metal & $\begin{array}{l}15-5 \mathrm{PH} \\
\text { Stainless } \\
\text { Steel }\end{array}$ & $F$ & $\begin{array}{l}\text { 15-5 PH stainless steel is flammable as an } 1 / 8 " \text { rod } \\
\text { in } 100 \% \text { oxygen at pressures above } 150 \text { psia. } \\
\text { (WSTF \# 07-41720). Thin cross sections of } \\
\text { stainless steel are flammable in } \\
100 \% \text { oxygen at ambient pressure (ASTM Manual } \\
36,2 \text { nd Ed., Tables 3-2 and 3-3). }\end{array}$ \\
\hline Magnet & Metal & $\begin{array}{l}\text { Samarium } \\
\text { Cobalt }\end{array}$ & $\mathrm{F}$ & $\begin{array}{l}\text { Material flammability data for samarium cobalt } \\
\text { could not be located. Therefore, it is assumed to be } \\
\text { flammable in } 100 \% \text { oxygen. }\end{array}$ \\
\hline Ball & $\begin{array}{l}\text { Non- } \\
\text { Metal }\end{array}$ & $\begin{array}{l}\text { Silicon } \\
\text { Nitride }\end{array}$ & $\mathrm{N}$ & $\begin{array}{l}\text { In six tests, ranging in pressure from } 1,000 \text { psi to } \\
10,000 \text { psi, silicon nitride did not propagate past the } \\
\text { promoter (ASTM STP 1111, pp. 354-364). This } \\
\text { result is consistent with the fact that ceramics are } \\
\text { considered to be inert. }\end{array}$ \\
\hline Epoxy & $\begin{array}{l}\text { Non- } \\
\text { Metal }\end{array}$ & EA 9394 & $\mathrm{~F}$ & $\begin{array}{l}\text { Epoxy is assumed to be flammable in these } \\
\text { conditions. }\end{array}$ \\
\hline
\end{tabular}




\begin{tabular}{|c|c|c|c|c|}
\hline $\begin{array}{l}\text { Rotor } \\
\text { Front } \\
\text { Plate }\end{array}$ & Metal & $\begin{array}{c}\text { Inconel } \\
718\end{array}$ & $\mathrm{~N}$ & $\begin{array}{l}\text { Inconel } 718 \text { configured as a } 1 / 8 \text {-in. rod supports } \\
\text { combustion at } 500 \text { psia (MAPTIS Test Rpt. No. } \\
\text { M104778-B). However, Inconel } 718 \text { was not tested } \\
\text { below } 500 \text { psia. By comparison of composition, } \\
\text { Inconel } 718 \text { can be considered at least as oxygen } \\
\text { compatible as } 316 \mathrm{~L} \text { stainless steel. } 316 \mathrm{~L} \text { stainless } \\
\text { steel is flammable as a } 1 / 8 \text {-in. rod in } 100 \% \text { oxygen } \\
\text { at pressures greater than } 111 \text { psia (ASTM MNL } 36 \text {, } \\
\text { 2nd. Ed., Table } 3-1 \text { ). Therefore, Inconel } 718 \text { is } \\
\text { considered flammable in } 100 \% \text { oxygen at pressures } \\
\text { greater than } 111 \text { psia. }\end{array}$ \\
\hline $\begin{array}{l}\text { Rotor } \\
\text { Rear } \\
\text { Plate }\end{array}$ & Metal & $\begin{array}{c}\text { Inconel } \\
718\end{array}$ & $\mathrm{~N}$ & $\begin{array}{l}\text { Inconel } 718 \text { configured as a } 1 / 8 \text {-in. rod supports } \\
\text { combustion at } 500 \text { psia (MAPTIS Test Rpt. No. } \\
\text { M104778-B). However, Inconel } 718 \text { was not tested } \\
\text { below } 500 \text { psia. By comparison of composition, } \\
\text { Inconel } 718 \text { can be considered at least as oxygen } \\
\text { compatible as } 316 \mathrm{~L} \text { stainless steel. } 316 \mathrm{~L} \text { stainless } \\
\text { steel is flammable as a } 1 / 8 \text {-in. rod in } 100 \% \text { oxygen } \\
\text { at pressures greater than } 111 \text { psia (ASTM MNL } 36 \text {, } \\
2 \text { nd. Ed., Table } 3-1 \text { ). Therefore, Inconel } 718 \text { is } \\
\text { considered flammable in } 100 \% \text { oxygen at pressures } \\
\text { greater than } 111 \text { psia. }\end{array}$ \\
\hline $\begin{array}{l}\text { Rotor } \\
\text { Band }\end{array}$ & Metal & $\begin{array}{c}\text { Inconel } \\
718\end{array}$ & $\mathrm{~N}$ & $\begin{array}{l}\text { Inconel } 718 \text { configured as a } 1 / 8 \text {-in. rod supports } \\
\text { combustion at } 500 \text { psia (MAPTIS Test Rpt. No. } \\
\text { M104778-B). However, Inconel } 718 \text { was not tested } \\
\text { below } 500 \text { psia. By comparison of composition, } \\
\text { Inconel } 718 \text { can be considered at least as oxygen } \\
\text { compatible as } 316 \mathrm{~L} \text { stainless steel. } 316 \mathrm{~L} \text { stainless } \\
\text { steel is flammable as a } 1 / 8 \text {-in. rod in } 100 \% \text { oxygen } \\
\text { at pressures greater than } 111 \text { psia (ASTM MNL } 36 \text {, } \\
2 \text { nd. Ed., Table } 3-1 \text { ). Therefore, Inconel } 718 \text { is } \\
\text { considered flammable in } 100 \% \text { oxygen at pressures } \\
\text { greater than } 111 \text { psia. }\end{array}$ \\
\hline Lubricant & $\begin{array}{l}\text { Non- } \\
\text { Metal }\end{array}$ & $\begin{array}{l}\text { Braycote } \\
814 Z\end{array}$ & $F$ & $\begin{array}{l}\text { Braycote } 814 Z \text { is considered flammable in } 100 \% \\
\text { oxygen at ambient pressure. }\end{array}$ \\
\hline $\begin{array}{l}\text { Bearing } \\
\text { Clamp }\end{array}$ & Metal & $\begin{array}{l}303 \\
\text { Stainless } \\
\text { Steel }\end{array}$ & $\mathrm{N}$ & $\begin{array}{l}300 \text { series stainless steel is considered flammable } \\
\text { in } 100 \% \text { oxygen at pressures above } 111 \text { psia } \\
\text { (ASTM MNL 36, 2nd. Ed., Table } 3-1 \text { ). }\end{array}$ \\
\hline $\begin{array}{l}\text { Inner } \\
\text { Sleeve }\end{array}$ & $\begin{array}{l}\text { Non- } \\
\text { Metal }\end{array}$ & Zirconia & $\mathrm{N}$ & $\begin{array}{l}\text { Material flammability data for zirconium oxide } \\
\text { (zirconia) is not available. However, because it is } \\
\text { already oxidized, it is assumed to be nonflammable } \\
\text { in } 100 \% \text { oxygen. Ceramics are generally } \\
\text { considered to be nonflammable. Therefore, } \\
\text { zirconium oxide (zirconia) is considered } \\
\text { nonflammable in these conditions. }\end{array}$ \\
\hline Impeller & Metal & $\begin{array}{l}\text { Anodized } \\
\text { Aluminum } \\
6061-T 6\end{array}$ & $F$ & $\begin{array}{l}\text { Aluminum } 6061-T 6 \text {, configured as a } 1 / 8 \text {-inch rod, } \\
\text { burned in } 100 \% \text { oxygen at } 10 \text { psia, and did not burn } \\
\text { in } 20 \text { tests at } 8 \text { psia (WSTF 09-3441). }\end{array}$ \\
\hline O-ring & Soft good & Viton & $F$ & $\begin{array}{l}\text { Viton is flammable in oxygen concentrations above } \\
56 \% \text { (ASTM STP 812, pp. 56-67). }\end{array}$ \\
\hline Volute & Metal & $\begin{array}{l}\text { Anodized } \\
\text { Cast } \\
\text { Aluminum }\end{array}$ & $F$ & $\begin{array}{l}\text { The type of aluminum used in this component is } \\
\text { unknown. However, aluminum } 5183 \text { (with a } \\
\text { minimum of } 92.1 \% \text { aluminum) is flammable as a } \\
1 / 8 \text {-in rod in } 100 \% \text { oxygen at ambient pressure }\end{array}$ \\
\hline
\end{tabular}


(ASTM STP 1267, pp.69-80). Therefore, the aluminum in this component is also considered flammable at ambient pressure.

$\begin{array}{llll}\text { Retainer Non- } & \text { Phenolic } & F & \text { Oxygen index data for phenolic fiber could not be }\end{array}$ Metal located. Phenolic fiber is assumed to be flammable in $100 \%$ oxygen.

\section{Recommendation/Conclusion}

The objectives of this testing effort were to replicate performance test results for the PLSS fan development unit, conduct further performance characterization testing, and conduct life testing. These objectives were met and the fan met or exceeded the design requirements for flow rate, delta pressure, and power usage. The initial life cycle testing showed that the fan development unit successfully performed throughout 740 hours of continuous testing.

The fan assembly design, and specifically the motor controller and bearing design, should be revisited and optimized based on future requirements for performance in an oxygen environment and packaging in the life support system. More life cycle testing is recommended to further determine the unit's potential for future use in a space suit exploration life support system.

\section{References}

${ }^{1}$ CTSD-CX-5117 JSC-65563, PLSS Baseline Schematics and Internal Interfaces, Bruce Conger and Eric Falconi ${ }^{2}$ ICES 2010 Fan paper

${ }^{3}$ Hamilton Final Report

4 JSC Performance Testing Final Report

5 JSC Life Cycle Testing Final Report

${ }^{6}$ WSTF OCA OXHAZ/FAIL.0430 